ARTIKEL

KEMAMPUAN MEMPRODUKSI TEKS ȦNEKDOT BERDASARKAN

STRUKTUR DAN KAIDAH KEBAHASAAN OLEH

SISWA KELAS X SMK MULTI KARYA

TAHUN PEMBELAJARAN

2016/2017

Oleh

Ratna Juwita

NIM 2133311068

Drs. Basyaruddin, M.Pd.

NIP 195809041986011001

Telah Diverifikasi dan Dinyatakan Memenuhi Syarat untuk

Diunggah pada Jurnal Online

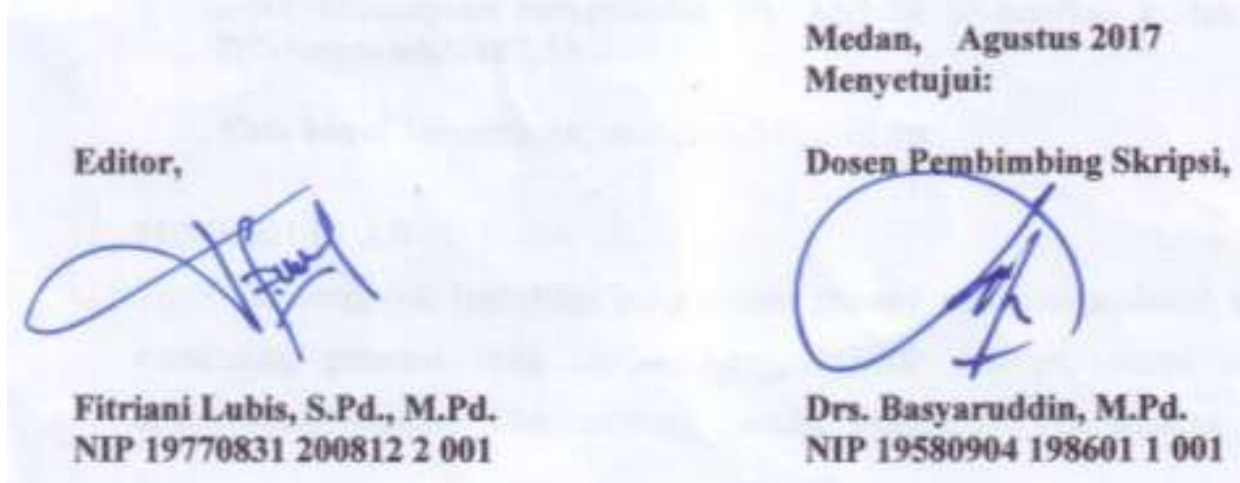




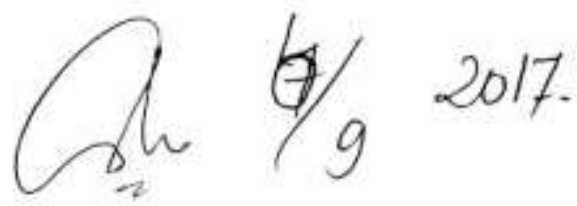

\title{
KEMAMPUAN MEMPRODUKSI TEKS ANEKDOT BERDASARKAN STRUKTUR DAN KAIDAH KEBAHASAAN OLEH SISWA KELAS X SMK MULTI KARYA TAHUN PEMBELAJARAN 2016/2017
}

\section{Oleh}

\author{
Ratna Juwita (juwita274@gmail.com) \\ Drs. Basyaruddin, M.Pd.
}

Teks anekdot adalah sebuah cerita singkat yang menarik karena lucu dan mengesankan. Sesuai dengan Silabus Kurikulum 2013 Edisi Revisi 2016, materi anekdot diajarkan pada jenjang SMA/SMK/MA kelas X maka penelitian ini dilaksanakan pada tingkat SMK kelas X. Tuntutan akan kemampuan siswa dalam memproduksi teks anekdot tertera pada kompetensi dasar 3.6 menganalisis struktur dan kebahasaan teks anekdot dan kompetensi dasar 4.6 menciptakan kembali teks anekdot dengan memerhatikan struktur, dan kebahasaan baik lisan maupun tulis. Penelitian mengenai teks anekdot ini dilaksanakan untuk mendeskripsikan bagaimana kemampuan siswa dalam memproduksi teks anekdot berdasarkan struktur dan kaidah kebahasaan. Metode yang digunakan adalah metode deskriptif kualitatif. Sumber data dalam penelitian ini adalah 39 orang siswa dan data dalam penelitian ini adalah 39 teks anekdot yang dihasilkan oleh siswa kelas X SMK Multi Karya. Dari hasil penelitian diperoleh bahwa nilai rata-rata kemampuan siswa kelas X SMK Multi Karya dalam memproduksi teks anekdot yaitu 80,64 dan berada pada kategori baik. Dengan kata lain siswa mampu untuk memproduksi teks anekdot dengan baik berdasarkan pada struktur dan kaidah kebahasaan. Nilai rata-rata aspek kemampuan memproduksi teks anekdot berdasarkan struktur teks adalah 96,41 dan nilai rata-rata aspek kemampuan memproduksi teks anekdot berdasarkan kaidah kebahasaan adalah 67,53.

Kata kunci: kemampuan, memproduksi, anekdot

\section{PENDAHULUAN}

Keterampilan berbahasa yang sangat penting peranannya dalam upaya melahirkan generasi yang cerdas, kritis, kreatif, dan profesional adalah keterampilan menulis. Keterampilan menulis merupakan keterampilan yang 
bersifat mekanistis. Keterampilan menulis tidak mungkin dikuasai hanya melalui teori, tetapi dilaksanakan melalui latihan dan praktik yang teratur sehingga menghasilkan tulisan yang tersusun baik. Keterampilan menulis menghendaki penguasaan berbagai unsur kebahasaan dan unsur di luar bahasa itu sendiri yang akan menjadi isi karangan. Bagi kebanyakan orang, menulis merupakan kegiatan yang menyenangkan. Bahkan bagi sebagian orang, menulis adalah sebuah keharusan. Kemampuan menulis setiap siswa tidak dapat diperoleh secara alamiah tetapi harus dilatih dan diasah. Melalui kegiatan menulis kita dapat mengungkapkan apa saja yang ada dalam pikiran dan perasaan.

Kurikulum 2013 mata pelajaran Bahasa Indonesia adalah pembelajaran berbasis teks. Pelajaran bahasa Indonesia tidak sekedar mengajarkan siswa untuk berbahasa dan bersastra saja, namun bahasa Indonesia juga digunakan sebagai sarana mengembangkan kemampuan dan keterampilan berpikir siswa. Dalam implementasinya, pembelajaran bahasa Indonesia menggunakan pendekatan berbasis teks. Dalam pembelajaran bahasa berbasis teks, bahasa Indonesia diajarkan bukan sekadar sebagai pengetahuan bahasa, melainkan sebagai teks yang mengemban fungsi untuk menjadi sumber aktualisasi diri penggunanya pada konteks sosial-budaya akademis.

Teks cerita adalah salah satu genre teks yang dipelajari dalam pembelajaran bahasa Indonesia pada Kurikulum 2013. Teks cerita yang terdapat pada silabus SMA sederajat salah satunya ialah teks anekdot. Teks anekdot adalah cerita singkat yang menarik karena lucu dan mengesankan. Teks anekdot merupakan materi pembelajaran yang diajarkan di sekolah sebagai suatu wahana kesusastraan. Teks anekdot sebagai sebuah karya sastra memiliki struktur yang membangun teks anekdot tersebut serta ciri kebahasaan yang membedakan teks anekdot dengan karya sastra lainnya. Sesuai dengan prinsip pembelajaran Bahasa Indonesia dalam kurikulum tersebut yakni berbasis teks. Teks anekdot menjadi salah satu teks yang wajib dipelajari siswa. Hanya saja teks anekdot baru dikenalkan mulai jenjang SMA/MA/SMK.

Salah satu tuntutan yang diharapkan dari siswa di dalam Kurikulum 2013 untuk mata pelajaran Bahasa Indonesia tingkat SMA sederajat adalah mampu 
menghasilkan produk pada setiap materi tidak terkecuali pada teks anekdot. Dan apabila dikaitkan dengan aspek pemahaman struktur, dan ciri kebahasaan teks anekdot, diharapkan siswa mampu memahami struktur, dan ciri kebahasaan teks anekdot tersebut. Hal ini merupakan salah satu kompetensi yang harus dicapai dalam Kurikulum 2013 Edisi Revisi pada kompetensi dasar 3.6 Menganalisis struktur dan kebahasaan teks anekdot dan kompetensi dasar 4.6 Menciptakan kembali teks anekdot dengan memerhatikan struktur, dan kebahasaan baik lisan maupun tulis.

Siswa dituntut untuk menunjukkan kemampuannya dalam memahami materi teks anekdot dengan cara mampu menulis atau memproduksi sebuah teks anekdot. Memproduksi teks anekdot berarti menghasilkan sebuah karangan yang bersifat menghibur atau lucu berdasarkan pengalaman diri sendiri maupun orang lain. Melalui pembelajaran teks anekdot siswa diharapkan mampu memahami struktur dan kaidah kebahasaannya sehingga siswa mampu memproduksi teks anekdot.

Sampai saat ini tidak dapat disangkal adanya suatu kemungkinan masih ada siswa yang kurang mampu untuk memproduksi teks anekdot. Dari hasil wawancara yang dilakukan di SMK Multi Karya dan berdiskusi dengan salah satu guru bidang studi Bahasa Indonesia diketahui bahwa siswa masih kesulitan dalam pelajaran bahasa Indonesia, dimana kemampuan siswa dalam memproduksi sebuah teks masih tergolong cukup dengan nilai rata-rata 70 . Sedangkan nilai KKM pada standar kompetensi di sekolah tersebut adalah 75. Berdasarkan wawancara dengan guru tersebut diketahui bahwa dalam pembelajaran memproduksi teks anekdot siswa mengalami kesulitan dalam menuangkan idenya untuk menghasilkan cerita yang bersifat lucu. Selain itu siswa juga kurang memahami beberapa aspek pada kaidah kebahasaan, khususnya dalam pemahaman mengenai pertanyaan retoris.

Kurikulum 2013 menuntut siswa untuk belajar secara aktif. Berdasarkan pengamatan peneliti selama PPLT di SMK Multi Karya, guru kurang efektif dalam menggunakan model ataupun metode pembelajaran yang sesuai dengan materi untuk menunjang perkembangan hasil belajar siswa. Dalam proses 
pembelajaran guru lebih menguasai kelas daripada siswa sehingga siswa menjadi merasa tidak ada tuntutan terhadap dirinya untuk lebih aktif dalam proses pembelajaran. Setelah melakukan wawancara dengan guru bidang studi Bahasa Indonesia, dan melihat langsung suasana belajar mengajar di SMK Multi Karya selama masa PPLT maka peneliti merasa tertarik untuk melakukan penelitian di sekolah tersebut. Hal itu didasarkan karena sekolah tersebut merupakan sekolah kejuruan yang mana siswanya lebih menyukai praktik daripada teori, sehingga peneliti merasa ingin mengetahui bagaimana ketertarikan siswa dalam pembelajaran yang berdasarkan teori, khususnya dalam hal memproduksi sebuah teks yaitu anekdot. Alasan lainnya adalah karena SMK Multi Karya merupakan sekolah PPLT peneliti, sehingga peneliti sudah mengenal lingkungan dalam sekolah dengan cukup baik.

Berdasarkan beberapa masalah yang ada, penulis tertarik untuk mendeskripsikan kemampuan siswa dalam memproduksi teks anekdot. Adapun judul yang dipilih sesuai permasalahan tersebut yaitu "Kemampuan Memproduksi Teks Anekdot Berdasarkan Struktur dan Kaidah Kebahasaan oleh Siswa Kelas X SMK Multi Karya Tahun Pembelajaran 2016/2017.”

\section{METODE PENELITIAN}

Metode penelitian dimaksudkan sebagai cara yang digunakan peneliti untuk menjawab permasalahan dalam penelitian. Oleh karena itu, metode penelitian sangat menentukan berhasil tidaknya suatu penelitian yang dilaksanakan. Sebagaimana yang diungkapkan Arikunto (2010:100), "Metode penelitian adalah cara yang dapat digunakan oleh peneliti untuk mengumpulkan data".

Penelitian ini menggunakan pendekatan kualitatif. Penelitian kualitatif perhatiannya lebih banyak ditujukan pada pembentukan teori substantif berdasarkan konsep-konsep yang timbul dari data empiris. Pengumpulan data dihasilkan dari penelitian bukanlah angka-angka, tetapi berupa kata-kata atau gambaran sesuatu yang disebut penelitian deskriptif. Oleh karena itu, penelitian ini merupakan penelitian deskriptif kualitatif. Karena penelitian ini dilakukan 
secara mendalam dan terperinci guna memperoleh deskripsi yang jelas terhadap kemampuan siswa dalam memproduksi teks anekdot.

Populasi dalam penelitian ini adalah seluruh siswa kelas X SMK Multi Karya tahun pembelajaran 2016/2017 yang berjumlah 428 siswa yang terdistribusi ke dalam 13 kelas. Lincoln dan Guba (dalam Sugiyono, 2008:301) menyatakan bahwa penentuan sampel dalam penelitian kualitatif sangat berbeda dengan penentuan sampel dalam penelitian kuantitatif. Penentuan sampel dalam penelitian kualitatif tidak didasarkan perhitungan statistik. Sampel yang dipilih berfungsi untuk mendapatkan informasi yang maksimum, bukan untuk digeneralisasikan. Dalam penelitian ini teknik pengambilan sampel yang digunakan adalah purposive sampling. Menurut Sugiyono (2008:300) purposive sampling adalah teknik pengambilan sampel sumber data dengan pertimbangan tertentu. Pertimbangan tertentu ini, misalnya orang tersebut yang dianggap paling tahu tentang apa yang kita harapkan, atau mungkin dia sebagai penguasa sehingga akan memudahkan peneliti menjelajahi objek/situasi sosial yang diteliti.

Peneliti akan meneliti mengenai kemampuan memproduksi teks anekdot, untuk mencapai tujuan penelitian tersebut, peneliti menentukan beberapa kriteria dalam menentukan sampel penelitian, dan terpilihlah siswa kelas X-Teknik Komputer Jaringan-1 (X TKJ-1) sebagai sampel dalam penelitian ini.

Penelitian ini merupakan penelitian kualitatif dengan metode studi dokumentasi. Data dalam penelitian ini adalah 39 teks anekdot yang dihasilkan oleh siswa kelas X TKJ-1 SMK Multi Karya Tahun Pembelajaran 2016/2017. Sesuai dengan jumlah sampel, maka sumber data dalam penelitian ini adalah 39 siswa kelas X TKJ-1 SMK Multi Karya Tahun Pembelajaran 2016/2017.

\section{HASIL PENELITIAN DAN PEMBAHASAN}

\section{A. Hasil Penelitian}

\section{Kemampuan Memproduksi Teks Anekdot Berdasarkan Struktur dan Kaidah Kebahasaan}

Data penelitian ini diolah dengan menggunakan teknik statistik deskripsi. Pengolahan data penelitian memproduksi teks anekdot berdasarkan struktur dan 
kaidah kebahasaan dilakukan dengan tahapan menghitung nilai rata-rata (mean) dan mempersentasekan nilai kemampuan siswa dengan menyusun tabel frekuensi data. Penilaian dalam penelitian ini meliputi dua aspek yaitu aspek struktur teks dan aspek kaidah kebahasaan teks.

Dari hasil analisis 39 teks anekdot yang dihasilkan siswa, dan setelah penggunaan rumus yang telah ditetapkan maka didapatlah nilai rata-rata aspek kemampuan memproduksi teks anekdot berdasarkan struktur teks adalah 96,41 dan termasuk dalam kategori sangat baik. Kemudian nilai rata-rata aspek kemampuan memproduksi teks anekdot berdasarkan kaidah kebahasaan adalah 67,53 dan termasuk dalam kategori cukup. Dan nilai rata-rata kemampuan memproduksi teks anekdot berdasarkan struktur dan kaidah kebahasaan yaitu 80,64 termasuk dalam kategori baik. Maka dapat disimpulkan bahwa kemampuan memproduksi teks anekdot oleh siswa kelas X SMK Multi Karya Tahun Pembelajaran 2016/2017 berada pada kategori baik. Dengan kata lain siswa mampu untuk memproduksi teks anekdot dengan baik berdasarkan pada struktur dan kaidah kebahasaan.

Data nilai kemampuan siswa memproduksi teks anekdot, apabila dilihat dari persentase siswa adalah sebanyak $14(35,9 \%)$ siswa berada pada rentang skor 86-100 termasuk dalam kategori sangat baik, sebanyak $12(30,77 \%)$ siswa berada pada rentang skor 76-85 termasuk dalam kategori baik, sebanyak 12 (30,77\%) siswa berada pada rentang skor 56-75 termasuk dalam kategori cukup, dan sebanyak $1(2,56 \%)$ siswa berada pada rentang 10-55 termasuk dalam kategori kurang.

\section{B. Pembahasan}

\section{Kemampuan Memproduksi Teks Anekdot Berdasarkan Struktur dan \\ Kaidah Kebahasaan}

Ada dua aspek penilaian dalam menilai kemampuan memproduksi teks anekdot dalam penelitian ini, yaitu kemampuan memproduksi teks berdasarkan struktur dan kemampuan memproduksi teks berdasarkan kaidah kebahasaan. Pada aspek penilaian berdasarkan struktur, siswa memperoleh nilai rata-rata 
kemampuan memproduksi teks anekdot berdasarkan struktur adalah 96,41 dan termasuk dalam kategori sangat baik.

Struktur teks anekdot ada lima, yaitu abstraksi, orientasi, krisis, reaksi, dan koda. Abstraksi adalah pendahuluan yang menyatakan latar belakang atau gambaran umum tentang isi suatu teks. Pada tahap ini siswa diminta menuliskan kisah awal dari teks anekdot mereka. Biasanya pada tahap ini berisi pengenalan tokoh, lokasi atau tempat kejadian, ataupun waktu dimana kejadian itu terjadi. Pada teks anekdot yang dihasilkan oleh siswa, mereka sudah mampu menuliskan teks anekdot yang berisikan tahap abstraksi di dalamnya. Rata-rata pada tahap ini siswa menerangkan kapan kejadian tersebut terjadi dan siapa saja para tokoh yang terlibat di dalam cerita mereka.

Struktur yang kedua adalah orientasi. Orientasi adalah bagian cerita yang mengarah pada terjadinya suatu krisis, konflik, atau peristiwa utama. Bagian inilah yang menjadi penyebab timbulnya krisis. Pada teks yang dihasilkan siswa, di tahap ini sudah mulai terlihat hal-hal yang menuju ke arah hal yang di anggap merupakan hal lucu, atau dalam teks anekdot disebut bagian krisis. Beberapa teks anekdot yang berkonsep percakapan, pada tahap ini percakapan antar tokoh dimulai. Dan pada teks yang menggunakan konsep narasi, pada tahap ini tindakan para tokohnya sudah mulai terlihat jelas.

Struktur anekdot yang ketiga adalah krisis. Krisis adalah bagian dari inti peristiwa suatu anekdot. Pada bagian itulah adanya kekonyolan yang menggelitik dan mengundang tawa. Dalam teks yang siswa hasilkan, di tahap ini terlihat halhal yang bersifat lucu, aneh atau bahkan membinggungkan yang ditimbulkan dari seorang tokoh sehingga timbullah timbal balik antara orang yang membuat hal lucu itu (tokoh pertama) dengan orang lain yang sedang berkomunikasi dengan tokoh pertama tersebut (tokoh kedua, dst) di dalam teks anekdot yang dihasilkan oleh para siswa.

Selanjutnya yang merupakan struktur keempat adalah reaksi. Reaksi merupakan tanggapan atau respons atas krisis yang dinyatakan sebelumnya. Reaksi atau tanggapan yang dimaksud dapat berupa sikap mencela, menertawakan, ataupun rasa binggung. Reaksi yang banyak dituliskan siswa 
dalam teks anekdot mereka adalah rasa lucu yang diperlihatkan dalam bentuk tertawa ataupun menertawakan tokoh pertama. Selain itu beberapa siswa membuat reaksi atau respon dalam bentuk rasa binggung yang dialami tokoh kedua atas tindakan tokoh pertama.

Pada keempat aspek di atas, semua nilai yang diperoleh termasuk kategori sangat baik, tapi berbeda halnya dengan tahap kelima yaitu koda. Koda adalah penutup atau kesimpulan sebagai pertanda berakhirnya cerita. Di dalamnya dapat berupa persetujuan, komentar, ataupun penjelasan atas maksud dari cerita yang dipaparkan sebelumnya. Keberadaan koda bersifat opsional; bisa ada ataupun tidak ada. Beberapa siswa di dalam teks anekdot mereka, cenderung tidak menyertakan koda atau akhir cerita di dalam teks yang mereka tulis. Hal inilah yang menyebabkan koda mendapatkan nilai terendah dari kelima struktur yang ada. Hal ini terjadi karena koda yang bersifat opsional, bisa ada bisa tidak. Ketika guru mereka mengatakan jika koda tidak wajib ada pada sebuah teks anekdot maka siswa beranggapan bahwa teks anekdot yang mereka hasilkan tidak mengapa jika tidak menyertakan koda di dalamnya. Tetapi di dalam instrumen atau soal yang peneliti berikan ketika melakukan penelitian, tertera bahwa struktur yang diminta ada lima, termasuk koda. Dan peneliti juga sudah memberikan instruksi sebelum siswa menghasilkan teks anekdot, untuk menyertakan koda di dalamnya. Jadi meskipun bersifat opsional, siswa tetap diminta untuk menuliskan koda atau akhir cerita dari anekdot yang mereka ciptakan tersebut. Tetapi dari hasil kerja siswa yang tertera pada lembar kerja, di dapatkan empat orang siswa tidak menuliskan bagian koda.

Berdasarkan penelitian yang telah dilakukan, aspek struktur memperoleh nilai lebih tinggi dibandingkan dengan kaidah kebahasaan. Hal ini menunjukkan bahwa siswa sudah lebih memahami struktur teks anekdot. Siswa juga sudah dapat menghasilkan sebuah teks sesuai dengan struktur teks tersebut dengan baik dan berurut.

Pada aspek penilaian berdasarkan kaidah kebahasaan, siswa memperoleh nilai rata-rata kemampuan memproduksi teks anekdot adalah 67,53 dan termasuk dalam kategori cukup. Aspek kaidah kebahasaan memperoleh kategori cukup, 
berbeda dengan aspek struktur yang memperoleh nilai baik sekali. Aspek ini pun memiliki rentang nilai yang cukup jauh dibandingkan dengan aspek struktur. Hal ini menunjukkan bahwa siswa masih belum memahami penggunaan kaidah kebahasaan yang terdapat pada teks anekdot sehingga untuk dapat membuat sebuah teks anekdot yang di dalamnya mencakup keenam kaidah kebahasaan tersebut dirasakan sulit oleh siswa.

Kaidah kebahasaan dalam teks anekdot ada enam yaitu menggunakan waktu lampau, menggunakan pertanyaan retoris, menggunakan kata penghubung (konjungsi) yang menyatakan hubungan waktu, menggunakan kata kerja aksi, menggunakan kalimat perintah dan menggunakan kata seru/ajakan. Dalam penjabaran selanjutnya di bawah ini akan dipaparkan mengenai setiap aspek penguasaan pada kaidah kebahasaan yang dikuasai siswa berdasarkan dari nilai yang tertinggi sampai yang terendah.

Nilai tertinggi pada aspek kaidah kebahasaan adalah penggunaan kata kerja aksi. Kata kerja aksi seperti membaca, menulis, berbicara dan sebagainya. Dari hasil penelitian didapatkan bahwa semua siswa mencantumkan kata kerja aksi di dalam teks yang mereka produksi. Hal ini tentu saja karena kata kerja aksi termasuk hal yang mudah dipahami oleh siswa. Dan kata kerja aksi tentu sangat sering digunakan dalam kehidupan sehari-hari.

Peringkat kedua dari aspek kebahasaan yang memperoleh nilai tertinggi adalah penggunaan waktu lampau. Dari hasil penelitian hanya dua orang siswa saja yang tidak menyertakan penggunaan waktu lampau dalam teks yang mereka produksi. Dalam teks anekdot yang diproduksi siswa, penggunaan kata "pada suatu hari" menjadi hal yang paling dominan mereka gunakan.

Selanjutnya yang berada pada posisi ketiga adalah menggunakan kata penghubung (konjungsi). Ada banyak kata penghubung, tetapi dalam teks anekdot kata penghubung yang dimaksud adalah kata penghubung yang menyatakan hubungan waktu seperti kemudian, selanjutnya, lalu dan sebagainya. Dari hasil penelitian terdapat tiga orang siswa yang tidak mencantumkan kata penghubung (konjungsi) ke dalam teks yang mereka produksi. Sebenarnya kata penghubung merupakan hal yang mudah untuk dipelajari dan dipahami, hal ini terlihat dari 
sudah mampunya semua siswa mencantumkan kata penghubung dalam teks yang mereka produksi, tetapi karena kata penghubung yang diminta dalam teks anekdot adalah kata penghubung yang lebih spesifik lagi, yaitu kata penghubung yang menerangkan hubungan waktu maka didapatlah tiga orang siswa yang tidak menggunakan aspek kebahasaan ini.

Ketiga aspek di atas, dapat dikatakan dikuasai dengan baik oleh siswa. Lain halnya dengan tiga aspek yang selanjutnya. Menggunakan kalimat seru/ajakan, menggunakan pertanyaan retoris, dan menggunakan kalimat perintah memiliki nilai yang rendah. Rentang nilai ketiga aspek tersebut jauh dari tiga aspek yang sebelumnya telah dipaparkan diatas. Menggunakan kalimat seru/ajakan menjadi peringkat keempat dari total enam kaidah kebahasaan pada teks anekdot. Dalam teks anekdot yang di tulis oleh siswa, penggunaan kata seru/ajakan sangat jarang ditemukan. Hal itu disebabkan karena dari segi cerita atau tema yang mereka angkat dalam teks anekdotnya, susah untuk memasukkan penggunaan kata seru/ajakan di dalamnya. Sama halnya juga dengan penggunaan kalimat perintah. Siswa merasakan sulit untuk bisa memasukkan kedua hal tersebut dalam teks anekdot mereka.

Pertanyaan retoris adalah pertanyaan yang tidak membutuhkan jawaban. Pertanyaan retoris menjadi hal yang dianggap siswa sulit untuk dipahami. Kurangnya pemahaman akan hal ini menyebabkan banyak siswa tidak menuliskan pertanyaan retoris pada teks anekdotnya. Kurangnya pemahaman akan pertanyaan retoris, peneliti ketahui ketika melakukan penelitian. Saat diminta memproduksi teks, banyak pertanyaan yang diutarakan para siswa terkait beberapa hal mengenai teks anekdot yang kurang mereka pahami. Dan pertanyaan terbanyak yang muncul dari siswa adalah mengenai pertanyaan retoris. Apa itu pertanyaan retoris, dan bagaimana membuat pertanyaan retoris membuat siswa merasa binggung sehingga enggan menyertakan hal tersebut dalam teks anekdotnya. Hal inilah yang peneliti yakini sebagai alasan mengapa pada aspek ini nilai yang diperoleh rendah. 


\section{SIMPULAN}

Dari hasil perhitungan di atas, terlihat bahwa kemampuan memproduksi teks anekdot dapat dikatakan baik, karena nilai rata-rata berada pada kategori baik. Hal ini disebabkan karena kemampuan siswa yang sudah bisa menghasilkan ataupun memproduksi sebuah teks anekdot secara baik dengan memenuhi kelima struktur yang ada secara runtun. Meskipun pada aspek kaidah kebahasaan, siswa masih merasa sulit untuk bisa menyertakan sekaligus keenam kaidahnya ke dalam teks yang mereka hasilkan. Hal ini bisa di atasi dengan lebih seringnya siswa membaca teks anekdot yang ada, baik di buku sekolah, maupun di media-media lainnya, sehingga bisa dijadikan bahan referensi ataupun acuan bagaimana menghasilkan anekdot dengan memenuhi kelima struktur dan keenam kaidah kebahasaannya tersebut. Dan kepada guru bidang studi agar lebih mampu menunjukkan kepada siswa contoh-contoh dari teks anekdot yang lebih bervariasi lagi, dan tentunya memenuhi kelima struktur dan enam kaidah kebahasaannya. Selain itu diharapkan agar guru mampu untuk lebih memberikan pemahaman yang dalam mengenai kaidah kebahasaan terutama pada tiga aspek yang memiliki nilai rendah.

\section{DAFTAR PUSTAKA}

Arikunto, Suharsimi. 2010 . Prosedur Penelitian Suatu Pendekatan Praktek. Jakarta: Rineka Cipta.

Kemendikbud. 2014. Bahasa Indonesia Ekspresi Diri dan Akademik. Jakarta: Kementerian Pendidikan dan Kebudayaan.

Kemendikbud. 2015. Bahasa Indonesia. Jakarta: Kementerian Pendidikan dan Kebudayaan.

Kosasih, Engkos. 2014. Jenis-jenis Teks. Bandung: Yrama Widya.

Sugiyono. 2008. Metode Penelitian Pendidikan Pendekatan Kuantitatif, Kualitatif, dan R\&D. Bandung: Alfabeta.

Tarigan, Henry Guntur. 2002. Menulis sebagai Suatu Keterampilan Berbahasa. Bandung: Angkasa. 